\title{
Orange Pickeringite from the Algares 30-Level Adit, Aljustrel Mine, Iberian Pyrite Belt, Portugal
}

\author{
Teresa P. Silva ${ }^{1, *(\mathbb{D}}$, João X. Matos ${ }^{2}$, Daniel de Oliveira ${ }^{1}$, Igor Morais ${ }^{2}$, Pedro Gonçalves ${ }^{2}$, Luís Albardeiro ${ }^{2}$, \\ Fernanda Carvalho ${ }^{3}\left(0\right.$, Ugur D. Menda ${ }^{3}$ and João P. Veiga ${ }^{3,4}(\mathbb{C}$ \\ 1 LNEG (National Laboratory for Energy and Geology), Mineral Resources and Geophysics Research Unit, \\ Estrada da Portela, 2610-999 Amadora, Portugal; daniel.oliveira@lneg.pt \\ 2 LNEG (National Laboratory for Energy and Geology), Mineral Resources and Geophysics Research Unit, \\ Bairro de Val d'Oca, 7601-909 Aljustrel, Portugal; joao.matos@lneg.pt (J.X.M.); igor.morais@lneg.pt (I.M.); \\ pedro.goncalves@lneg.pt (P.G.); luis.albardeiro@lneg.pt (L.A.) \\ 3 CENIMAT/i3N (Materials Research Centre), Department of Materials Science, NOVA School of Sciences and \\ Technology (FCT-NOVA), NOVA University of Lisbon, 2829-516 Caparica, Portugal; \\ fb.carvalho@campus.fct.unl.pt (F.C.); u.menda@fct.unl.pt (U.D.M.); jpv@fct.unl.pt (J.P.V.) \\ 4 Department of Conservation and Restoration, NOVA School of Sciences and Technology, NOVA University of \\ Lisbon, 2829-516 Caparica, Portugal \\ * Correspondence: teresa.pena@lneg.pt
}

Citation: Silva, T.P.; Matos, J.X.; de Oliveira, D.; Morais, I.; Gonçalves, P.; Albardeiro, L.; Carvalho, F.; Menda, U.D.; Veiga, J.P. Orange Pickeringite from the Algares 30-Level Adit, Aljustrel Mine, Iberian Pyrite Belt, Portugal. Minerals 2021, 11, 1115. https://doi.org/10.3390/min11101115

Academic Editor: Stefan Peiffer

Received: 16 September 2021

Accepted: 7 October 2021

Published: 11 October 2021

Publisher's Note: MDPI stays neutral with regard to jurisdictional claims in published maps and institutional affiliations.

Copyright: (c) 2021 by the authors. Licensee MDPI, Basel, Switzerland. This article is an open access article distributed under the terms and conditions of the Creative Commons Attribution (CC BY) license (https:// creativecommons.org/licenses/by/ $4.0 /)$.

\begin{abstract}
The sheltered environment of the Algares +30 level adit (underground mine gallery) contributes to the preservation of secondary water-soluble minerals formed on the tunnel walls. The massive sulphide and related stockwork zone are hosted by the Mine Tuff volcanic unit and are exposed in the walls of the gallery, showing intense oxidation and hydrothermal alteration. Minerals from the halotrichite group were identified on the efflorescent salts, typically white fine-acicular crystals but also on aggregates with dark orange/brownish colour. Mineral characterization was performed using several methods and analytical techniques (XRD, XRF-WDS, SEM-EDS, DTA-TG), and the chemical formulas were calculated maintaining the ratio $A: B \cong 1: 2$ in accordance with the general formula of the halotrichite group, $\mathrm{AB}_{2}\left(\mathrm{SO}_{4}\right)_{4} \cdot 22 \mathrm{H}_{2} \mathrm{O}$. This methodology allowed the assignment of the orange colour to the presence of trivalent iron on iron-rich pickeringite in partial substitution of aluminium.
\end{abstract}

Keywords: orange pickeringite; halotrichite; efflorescent minerals; underground mining; Algares mine; Iberian Pyrite Belt sulphide ores

\section{Introduction}

The Aljustrel Mine is located in the Portuguese sector of the Iberian Pyrite Belt (IPB), one of the most important European metallogenic provinces, with more than 90 deposits of polymetallic massive sulphide ores [1,2]. The mine site contains six ore lenses, namely, Estação, Feitais, Algares, Moinho, São João and Gavião. Feitais and Moinho are being exploited by the Almina Company. The mining area also includes the old Pedras Brancas Metallurgical Complex (approximately $10 \mathrm{~km}$ ESE of Aljustrel) [3-6]. At Algares and São João, deposit mining activity occurred prior to and during the Roman Empire's occupation of the Iberian Peninsula. As the Algares orebody is vertical and relatively thin, mining was never developed in a large open pit setting [7]; the exploitation was mainly for copper, lead and zinc, with gold and silver as by-products. The sulphide mineral assemblages of the orebody consist mostly of pyrite $\left(\mathrm{FeS}_{2}\right)$ and minor amounts of sphalerite $(\mathrm{ZnS})$, chalcopyrite $\left(\mathrm{CuFeS}_{2}\right)$, galena $(\mathrm{PbS})$, arsenopyrite $(\mathrm{FeAsS})$, tetrahedrite $\left[(\mathrm{Cu}, \mathrm{Ag})_{10}(\mathrm{Fe}, \mathrm{Zn})_{2} \mathrm{Sb}_{4} \mathrm{~S}_{13}\right]$, tennantite $\left[(\mathrm{Cu}, \mathrm{Ag})_{10}(\mathrm{Fe}, \mathrm{Zn})_{2} \mathrm{As}_{4} \mathrm{~S}_{13}\right]$, stannite $\left(\mathrm{Cu}_{2} \mathrm{FeSnS}_{4}\right)$, pyrrhotite $\left(\mathrm{Fe}_{1-\mathrm{x}} \mathrm{S}\right)$ and some native bismuth [8]. The outcropping Algares deposit forms a NW-SE orientated narrow gossan, mapped along $900 \mathrm{~m}$ [9-11]. 
In the 19th century, modern exploration began mainly through wells or adits (galleries), reaching a depth of about $360 \mathrm{~m}$ [12-15]. Presently, the deposit is considered exhausted and the area is being rehabilitated for mining and geological tourism. To promote new educational visits, the Company Empresa de Desenvolvimento Mineiro (EDM) and the Aljustrel Municipality carried out rehabilitation works inside the Algares +30 level adit (approximately $500 \mathrm{~m}$ long). During the mine rehabilitation project, the Algares mine gallery was cleaned and enlarged for public visits. Protection structures were constructed including wood pillars, concrete walls and metallic networks. Thematic underground visits will be promoted by the Aljustrel Municipality, including in the future Aljustrel Mining Park.

The Algares +30 level adit intersects two distinct volcanic units of the IPB VolcanoSedimentary Complex (Tournaisian-Late Visean age at the Aljustrel Antiform) [16]. The massive sulphide and related stockwork zone are hosted by the Mine Tuff volcanic unit and are exposed in the walls of the gallery, showing intense hydrothermal alteration. The primary mineralization is strongly affected by supergene oxidation alteration due to the near surface location of the studied mine gallery. The two gossans Algares Oeste and Algares Este are present in the gallery. The oxides and sulphides in the moist air resulted in the formation of simple and complex multi-coloured sulphates (secondary minerals), making the adit a natural "mineralogical museum". These particular conditions include direct access to the Vipasca mine shaft (and connection with deeper flooded mine levels) and old Roman mine galleries (with 2000 years of mineral exposure to the open air). In summary, the minerals present in the mine gallery are: primary mineralization (sulphides + sulphosalts + hydrothermal assemblage, e.g., chlorite and sericite), supergene-oxidationstage mineralization (e.g., hematite, goethite, limonite) and neoformation minerals/crystals (e.g., oxides, hydroxides, sulphates). The sheltered environment of this underground mine gallery contributes to the preservation of water-soluble minerals. The most common minerals found were melanterite $\left(\mathrm{FeSO}_{4} \cdot 7 \mathrm{H}_{2} \mathrm{O}\right)$ and chalcanthite $\left(\mathrm{CuSO}_{4} \cdot 5 \mathrm{H}_{2} \mathrm{O}\right)$, resulting from the weathering brought about by the percolation of acidic fluids and forming essentially massive or crystalline aggregates, ranging from greenish to bluish colours [16]. Other minerals identified in the walls of the adit, including those prevailing in stalactites/stalagmites, were: alunite $\left[(\mathrm{K}, \mathrm{Na}) \mathrm{Al}_{3}\left(\mathrm{SO}_{4}\right)_{2}(\mathrm{OH})_{6}\right]$, alunogen $\left[\mathrm{Al}_{2}\left(\mathrm{SO}_{4}\right)_{3} \cdot 17 \mathrm{H}_{2} \mathrm{O}\right]$, antlerite $\left[\mathrm{Cu}_{3}\left(\mathrm{SO}_{4}\right)(\mathrm{OH})_{4}\right]$, atacamite $\left[\mathrm{Cu}_{2} \mathrm{Cl}(\mathrm{OH})_{3}\right]$, copiapite $\left[\mathrm{Fe}_{5}\left(\mathrm{SO}_{4}\right)_{6}(\mathrm{OH})_{2} \cdot 20 \mathrm{H}_{2} \mathrm{O}\right]$, fibroferrite $\left[\mathrm{Fe}^{3+}(\mathrm{OH}) \mathrm{SO}_{4} \cdot 5 \mathrm{H}_{2} \mathrm{O}\right]$, gypsum $\left(\mathrm{CaSO}_{4} \cdot 2 \mathrm{H}_{2} \mathrm{O}\right)$, jarosite $\left[\mathrm{KFe}_{3}\left(\mathrm{SO}_{4}\right)_{2}(\mathrm{OH})_{6}\right]$ and kaolinite $\left[\mathrm{Al}_{2} \mathrm{Si}_{2} \mathrm{O}_{5}(\mathrm{OH})_{4}\right][16]$.

Aqueous solutions of $\mathrm{Fe}^{2+} / \mathrm{Mg}^{2+}$ combined with $\mathrm{Al}^{3+}$ from the weathering of silicates gave rise to further mixed divalent-trivalent sulphate salts such as halotrichite $\left[\mathrm{FeAl}_{2}\left(\mathrm{SO}_{4}\right)_{4} \cdot 22 \mathrm{H}_{2} \mathrm{O}\right] /$ pickeringite $\left[\mathrm{MgAl}_{2}\left(\mathrm{SO}_{4}\right)_{4} \cdot 22 \mathrm{H}_{2} \mathrm{O}\right]$. Indeed, these minerals are frequently found in acid mine drainage (AMD) environments (e.g., [17-22]), but their presence as a coating of the gallery walls has preserved them from dissolution.

Minerals from the halotrichite group are usually colourless or white [23,24]. Colours like pale pink or yellow appear when $\mathrm{Mn}^{2+}$ or $\mathrm{Fe}^{3+}$ are present, respectively [25]. The possibility of a $\mathrm{Fe}^{3+}$ substitution for $\mathrm{Al}$ is also foreseen [19,25-27]. Furthermore, Parafiniuk [25] points out that $\mathrm{Fe}^{3+}$ rich pickeringite may be distinguished macroscopically by its colour (creamy, yellow, light brown of various tints), while pure pickeringite is white. He also mentions that $\mathrm{Fe}^{3+}$-rich pickeringite is much darker than in its dry state, and could even have a chocolate colour, which gradually changes to pale-brown and yellow upon drying.

In fact, it was the dark orange/brownish colour of some aggregates, in contrast to the typically white fine-acicular crystals, that caught our attention. It was specifically this aspect that gave rise to this thorough mineralogical (XRD) study on minerals from the halotrichite group, particularly concerning white halotrichite, as well as white and orange pickeringite, from the Algares adit. Chemical analysis (XRF-WDS), scanning electron microscopy (SEM-EDS) and thermo-analytical techniques (DTA-TG) were also used to characterize the efflorescent samples, aiming to contribute to the knowledge of the unusual orange pickeringite. 


\section{The Halotrichite Group}

Sulphates of the halotrichite group (monoclinic, S.G. $P 2_{1} /$ c) have the general formula $\mathrm{AB}_{2}\left(\mathrm{SO}_{4}\right)_{4} \cdot 22 \mathrm{H}_{2} \mathrm{O}$, where $\mathrm{A}=\mathrm{Fe}^{2+}, \mathrm{Mg}^{2+}, \mathrm{Mn}^{2+}, \mathrm{Ni}^{2+}, \mathrm{Zn}^{2+}$ and $\mathrm{B}=\mathrm{Al}^{3+}, \mathrm{Cr}^{3+}, \mathrm{Fe}^{3+}[26,28]$. There is complete miscibility between $\mathrm{Mg}^{2+}$ and $\mathrm{Fe}^{2+}$ in the pickeringite $\left(\mathrm{A}=\mathrm{Mg}^{2+}\right)-$ halotrichite $\left(\mathrm{A}=\mathrm{Fe}^{2+}\right)$ series, the substitution of aluminium $\left(\mathrm{B}=\mathrm{Al}^{3+}\right)$ by $\mathrm{Fe}^{3+}$ being restricted [24,29]. Bilinite $\left[\mathrm{Fe}^{2+} \mathrm{Fe}^{3+}{ }_{2}\left(\mathrm{SO}_{4}\right)_{4} \cdot 22 \mathrm{H}_{2} \mathrm{O}\right]$ is a ferric iron analogue of halotrichite $\left[\mathrm{Fe}^{2+} \mathrm{Al}^{3+}{ }_{2}\left(\mathrm{SO}_{4}\right)_{4} \cdot 22 \mathrm{H}_{2} \mathrm{O}\right]$, which is isostructural. There is also ternary solid solution $\mathrm{Mg}^{2+}$ $\mathrm{Fe}^{2+}$ with apjohnite $\left(\mathrm{A}=\mathrm{Mn}^{2+}\right)$ and similarly with dietrichite $\left(\mathrm{A}=\mathrm{Zn}^{2+}\right)[26,30]$. The other species of the halotrichite group are uncommon [28]. Due to the occurrence of solid solutions and to the similar powder diffraction patterns, the identification of these minerals is difficult $[25,27,31,32]$. Moreover, the accurate crystal-chemical characterisation has been problematic because of the impossibility of obtaining pure samples due to the small dimension of the crystals and by the occurrence in nature of very complex mixtures with other sulphates [30,33].

The structure of these minerals (an example of pickeringite in Figure 1) is based on finite clusters of $\left(\mathrm{SO}_{4}\right)$ tetrahedra (four per asymmetric unit), one $\mathrm{A}_{6}$ octahedra ( $\varnothing=$ five water oxygens plus one sulphate oxygen) and two independent $B \varnothing_{6}$ octahedra $(\varnothing=$ six water oxygens). There are seventeen ligand water molecules and five isolated water molecules $[29,33,34]$.

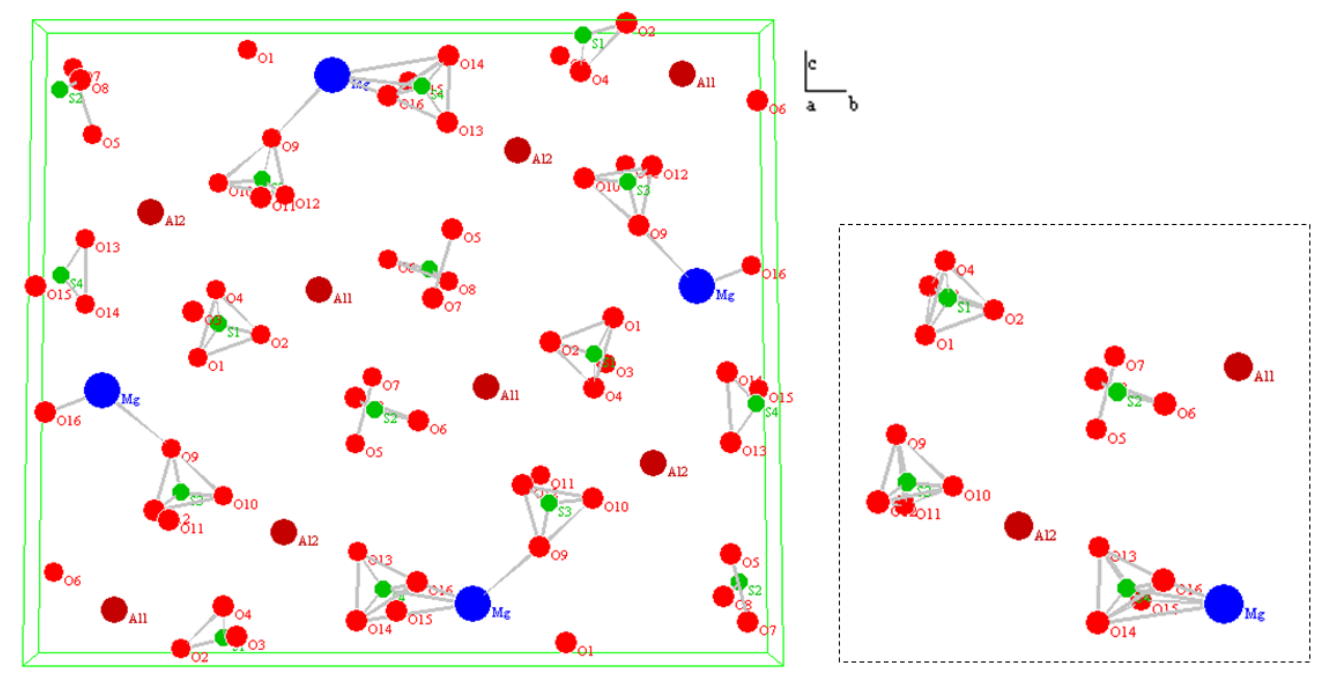

Figure 1. Sketch of the pickeringite structure: $\mathrm{MgAl}_{2}\left(\mathrm{SO}_{4}\right)_{4} \cdot 22 \mathrm{H}_{2} \mathrm{O}$, obtained with PowderCell program [35]. The water molecules are not represented for simplification: left side-unit cell, right side-asymmetric unit.

\section{Materials and Methods}

More than 100 efflorescent samples were collected in September 2018 from the walls of the Algares +30 level adit along its entire length, considering both colour and crystal morphology [16]. From those, 19 are the focus of the present study. Several fragments for X-ray diffraction (XRD) were selected (25) using the stereomicroscope (Stemi SV-11, Zeiss, Jena, Germany), with images collected using a digital Zeiss camera (Axio-Cam Mrc, Jena, Germany). Several images were mustered from the same fragment with the focus set at different levels, all of which were compiled together in Adobe Photoshop ${ }^{\mathrm{TM}}$ using the focus stacking method.

For X-ray diffraction (XRD), a Philips PW 1500 powder diffractometer (Philips, Aachen, Germany) with Bragg-Brentano geometry was used, equipped with a large-anode copper tube operating at $50 \mathrm{kV}-40 \mathrm{~mA}$ and a curved graphite crystal monochromator. A semiquantitative chemical analysis was also performed through $\mathrm{X}$-ray fluorescence spectrometry with a wavelength dispersive system (XRF-WDS), using a PANalytical 4.0 AXIOS sequential spectrometer (Rh X-ray tube) (Malvern PANalytical, Malvern, UK) under He flow. 
SEM-EDS was performed using a tabletop scanning electron microscope (Hitachi TM3030Plus) (Hitachi High-Technologies Corporation, Tokyo, Japan), coupled with a Quantax70 Energy Dispersive X-Ray Spectrometer, operated at an acceleration voltage of $15 \mathrm{kV}$ at ambient temperature and under low vacuum.

Samples were mounted with no preparation (non-destructive characterization) using a double-sided carbon tape.

Thermo-analytical techniques-simultaneous differential thermal analysis (DTA) and thermogravimetry (TG) - were also used, using a SETARAM 92-16.18 apparatus (KEP Technologies Group, Sophia Antipolis, France), incorporating a microbalance with a controlled argon gas flow (inert atmosphere). About $60 \mathrm{mg}$ of milled sample were deposited in an alumina $\left(\alpha-\mathrm{Al}_{2} \mathrm{O}_{3}\right)$ crucible. The reference material was alumina powder. Therefore, the DTA-TG assays were performed in a heating temperature range from ambient to $1000{ }^{\circ} \mathrm{C}$, at a heating rate of $10^{\circ} \mathrm{C} \mathrm{min}^{-1}$.

\section{Results and Discussion}

Minerals from the halotrichite group were identified in 25 fragments, the majority as whitish pickeringite, two iron-rich pickeringite (orange) and one white halotrichite. They were mainly in mixtures with melanterite, but also with alunogen or chalcanthite, over quartz + pyrite, quartz + hematite, jarosite + quartz or quartz + chlorite/clinochlore + mica. The stability of halotrichite group minerals with alunogen or melanterite in saturated solutions has already been mentioned [26]. These sulphates occurred mainly as white fine-acicular crystals (Figures 2 and 3) but also as orange/brownish aggregates of crystals in two samples (Figure 4). Indeed, the orange samples collected in September 2018 [16] and kept in the laboratory in sealed containers are now brown/yellowish with a dry appearance in some zones. The halotrichite group minerals were formed over felsic volcanic rocks with stockwork and disseminated mineralization. Generally, these rocks are well-cleaved and present hydrothermal alteration (chlorite \pm sericite).

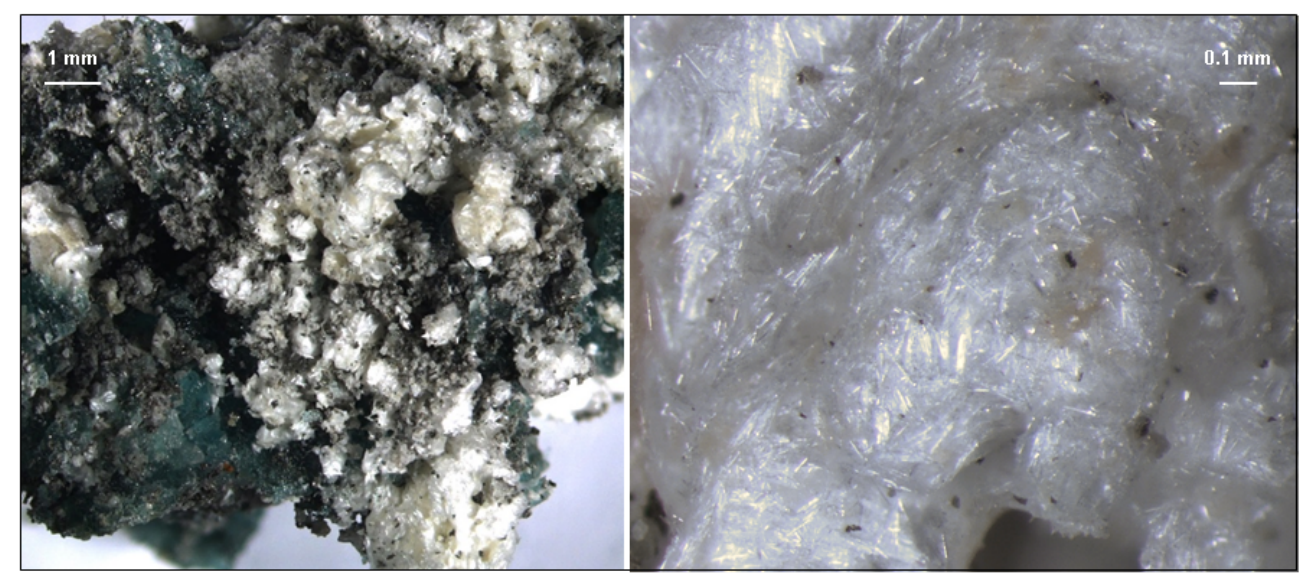

Figure 2. Stereomicroscope images of halotrichite (sample 20-white). 


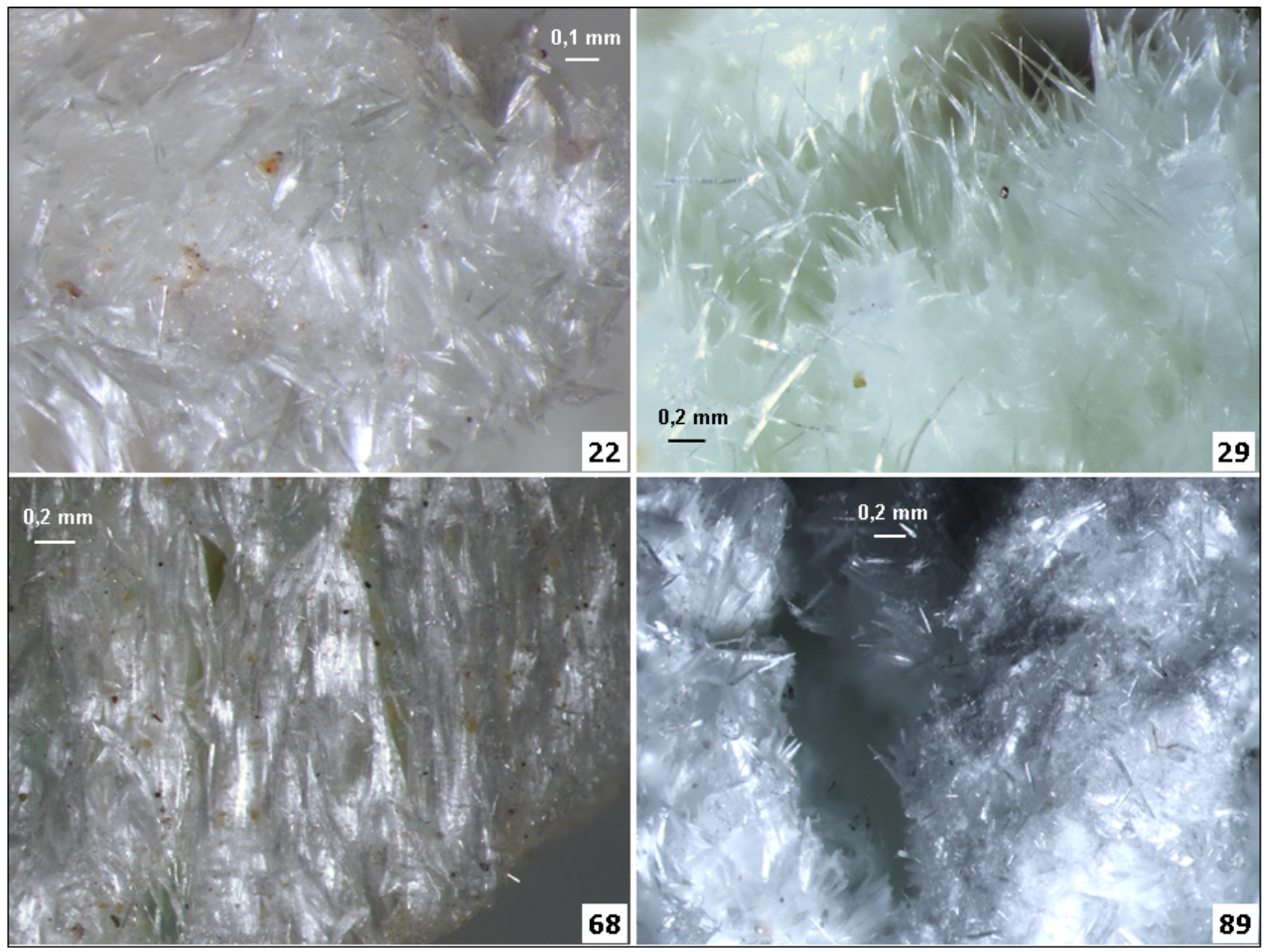

Figure 3. Stereomicroscope images of white pickeringite (samples reference 22, 29, 68 and 89).
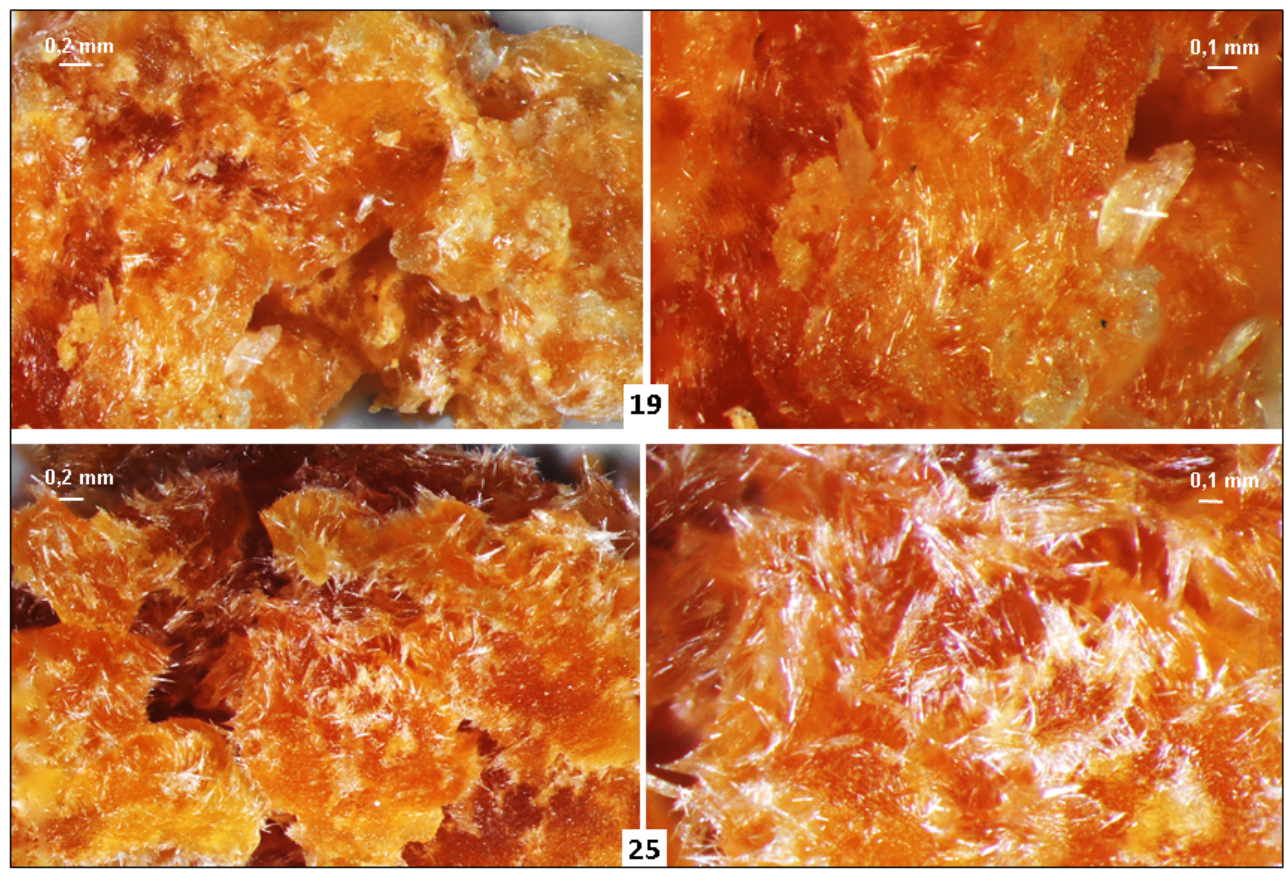

Figure 4. Stereomicroscope images of orange pickeringite (samples 19 and 25).

Figure 5 displays an example of very similar XRD patterns, obtained for four samples (white and orange) chosen for the presence of only one phase, halotrichite/pickeringite (see Table 1). 


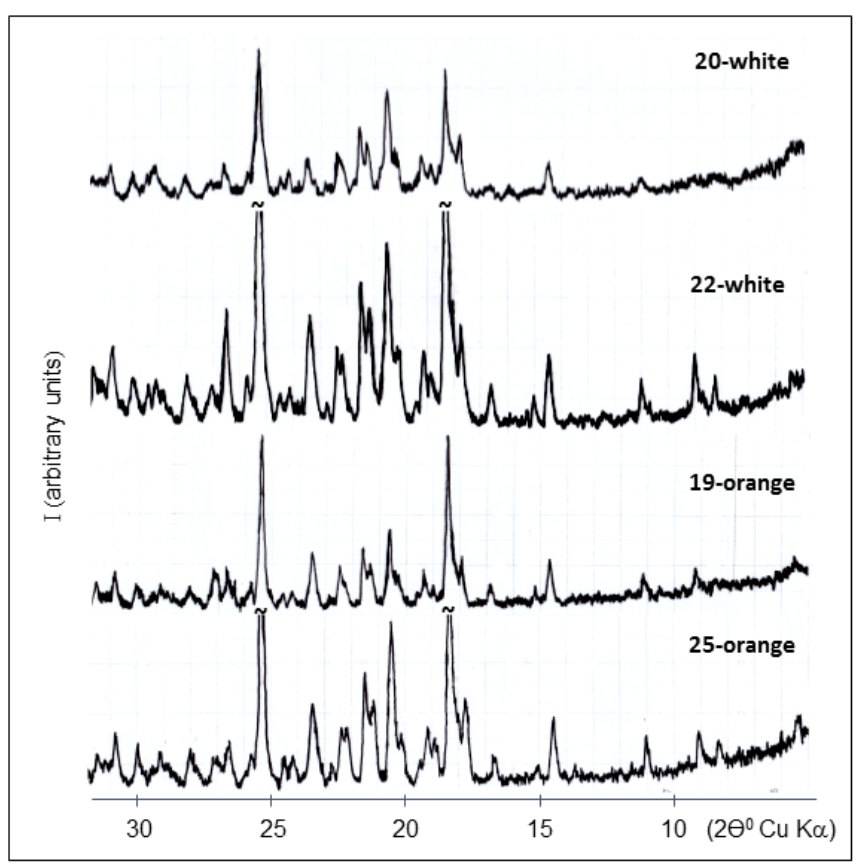

Figure 5. XRD patterns obtained for white and orange samples. All peaks are from pickeringite/halotrichite.

Table 1. JCPDF cards for minerals (obtained with radiation $\mathrm{Cu} \mathrm{K} \alpha$ ) from the halotrichite group (the three more intense lines are assigned in bold): halotrichite, $\mathrm{FeAl}_{2}\left(\mathrm{SO}_{4}\right)_{4} \cdot 22 \mathrm{H} 2 \mathrm{O}$ (number 39-1387); pickeringite, $\mathrm{MgAl}_{2}\left(\mathrm{SO}_{4}\right)_{4} \cdot 22 \mathrm{H}_{2} \mathrm{O}$ (46-1454); apjohnite, $\mathrm{MnAl}_{2}\left(\mathrm{SO}_{4}\right)_{4} \cdot 22 \mathrm{H}_{2} \mathrm{O}$ (29-0886); dietrichite, $\mathrm{ZnAl}_{2}\left(\mathrm{SO}_{4}\right)_{4} \cdot 22 \mathrm{H}_{2} \mathrm{O}(25-1173)$; bilinite, $\mathrm{Fe}^{2+} \mathrm{Fe}^{3+}{ }_{2}\left(\mathrm{SO}_{4}\right)_{4} \cdot 22 \mathrm{H}_{2} \mathrm{O}(25-1153)$.

\begin{tabular}{|c|c|c|c|c|c|c|c|c|c|}
\hline \multicolumn{2}{|c|}{ Halotrichite } & \multicolumn{2}{|c|}{ Pickeringite } & \multicolumn{2}{|c|}{ Apjohnite } & \multicolumn{2}{|c|}{ Dietrichite } & \multicolumn{2}{|c|}{ Bilinite } \\
\hline $2 \theta^{\circ}$ & Int. & $2 \theta^{\circ}$ & Int. & $2 \theta^{\circ}$ & Int. & $2 \theta^{\circ}$ & Int. & $2 \theta^{\circ}$ & Int. \\
\hline 5.6 & 20 & - & - & - & - & 5.3 & 5 & - & - \\
\hline 7.3 & 8 & - & - & - & - & - & - & - & - \\
\hline 8.4 & 15 & 8.5 & 4 & 8.3 & 10 & 8.2 & 5 & - & - \\
\hline 9.2 & 18 & 9.2 & 13 & 9.2 & 10 & 9.0 & 5 & - & - \\
\hline 11.2 & 15 & 11.1 & 9 & 11.1 & 10 & 11.0 & 5 & - & - \\
\hline- & - & - & - & - & - & - & - & 12.1 & 10 \\
\hline 14.7 & 35 & 14.6 & 22 & 14.6 & 20 & 14.5 & 15 & 14.6 & 10 \\
\hline 15.2 & 9 & 15.1 & 7 & 15.1 & 5 & - & - & - & - \\
\hline- & - & 15.7 & 20 & - & - & - & - & - & - \\
\hline- & - & 16.5 & 27 & 16.1 & 5 & - & - & 16.2 & 25 \\
\hline 16.8 & 7 & 16.7 & 13 & 16.8 & 8 & - & - & - & - \\
\hline- & - & - & - & 17.8 & 18 & 17.8 & 30 & 17.9 & 30 \\
\hline 18.0 & 21 & 18.0 & 49 & - & - & - & - & 18.1 & 5 \\
\hline 18.2 & 11 & - & - & 18.2 & 5 & 18.3 & 40 & 18.3 & 50 \\
\hline 18.6 & 100 & 18.5 & 100 & 18.4 & 90 & - & - & - & - \\
\hline 19.0 & 10 & 19.0 & 4 & 18.9 & 5 & 18.9 & 10 & 18.9 & 10 \\
\hline 19.4 & 12 & 19.3 & 13 & 19.2 & 6 & 19.1 & 15 & 19.1 & 10 \\
\hline- & - & - & - & 20.1 & 6 & - & - & - & - \\
\hline 20.3 & 10 & 20.4 & 22 & 20.3 & 6 & - & - & - & - \\
\hline- & - & - & - & 20.5 & 30 & 20.5 & 100 & - & - \\
\hline 20.7 & 31 & 20.6 & 58 & 20.6 & 30 & - & - & 20.6 & 100 \\
\hline- & - & - & - & 21.2 & 12 & 21.1 & 20 & - & - \\
\hline 21.4 & 14 & 21.4 & 35 & - & - & 21.4 & 30 & 21.3 & 20 \\
\hline 21.7 & 20 & 21.6 & 47 & 21.5 & 20 & - & - & 21.6 & 40 \\
\hline 22.3 & 12 & - & - & 22.2 & 10 & 22.1 & 10 & - & - \\
\hline 22.5 & 21 & 22.4 & 18 & 22.4 & 25 & 22.4 & 10 & 22.5 & 10 \\
\hline 22.9 & 5 & - & - & 22.8 & 6 & - & - & - & - \\
\hline 23.7 & 27 & 23.5 & 42 & 23.5 & 35 & - & - & 23.5 & 5 \\
\hline 24.3 & 7 & 24.3 & 7 & 24.2 & 4 & 24.1 & 5 & - & - \\
\hline
\end{tabular}


Table 1. Cont.

\begin{tabular}{cccccccccc}
\hline \multicolumn{2}{c}{ Halotrichite } & \multicolumn{3}{c}{ Pickeringite } & \multicolumn{2}{c}{ Apjohnite } & \multicolumn{2}{c}{ Dietrichite } & \multicolumn{2}{c}{ Bilinite } \\
$\mathbf{2} \boldsymbol{\theta}^{\circ}$ & Int. & $\mathbf{2 \theta}^{\circ}$ & Int. & $\mathbf{2 \theta}^{\circ}$ & Int. & $\mathbf{2 \theta}^{\circ}$ & Int. & $\mathbf{2 \theta}^{\circ}$ & Int. \\
\hline 24.7 & 6 & 24.7 & 7 & 24.5 & 6 & 24.5 & 5 & - & - \\
$\mathbf{2 5 . 6}$ & $\mathbf{7 5}$ & $\mathbf{2 5 . 4}$ & $\mathbf{1 0 0}$ & $\mathbf{2 5 . 3}$ & $\mathbf{1 0 0}$ & $\mathbf{2 5 . 3}$ & $\mathbf{1 0 0}$ & $\mathbf{2 5 . 3}$ & $\mathbf{1 0 0}$ \\
25.9 & 10 & 25.8 & 18 & 25.8 & 11 & 26.0 & 15 & 25.8 & 25 \\
- & - & - & - & 26.5 & 8 & 26.5 & 5 & - & - \\
26.7 & 5 & 26.8 & 13 & 26.6 & 8 & - & - & - & - \\
- & - & - & - & 26.9 & 4 & - & - & - & - \\
27.1 & 7 & 27.1 & 9 & 27.1 & 4 & 27.2 & 5 & 27.1 & 30 \\
27.4 & 6 & - & - & 27.3 & 3 & - & - & - & - \\
27.9 & 2 & 27.9 & 4 & 27.8 & 3 & - & - & - & - \\
- & - & 28.1 & 11 & 28.1 & 10 & 28.0 & 10 & - & - \\
28.7 & 5 & - & - & 28.6 & 2 & 28.9 & 5 & - & - \\
29.2 & 8 & - & - & 29.2 & 9 & - & - & - & - \\
29.4 & 5 & 29.4 & 7 & 29.5 & 5 & - & - & - & - \\
30.1 & 10 & 30.1 & 13 & 30.0 & 15 & 29.9 & 10 & 30.0 & 15 \\
30.9 & 11 & 31.0 & 22 & 30.8 & 11 & 30.7 & 15 & 30.9 & 30 \\
\hline
\end{tabular}

As already mentioned, the mineralogical identification was very difficult due to the possibility of solid solution between the halotrichite group members. The free program PowderCell [35] was used to simulate the XRD pattern of pickeringite $\left[\mathrm{MgAl}_{2}\left(\mathrm{SO}_{4}\right)_{4} \cdot 22 \mathrm{H}_{2} \mathrm{O}\right]$ based on data published for the crystal structure, where the proportion of $\mathrm{Mg}: \mathrm{Mn} \mathrm{oc}-$ cupancy is 0.93:0.07 and the positions Al1 plus Al2 are completely occupied only by aluminium [31]. The substitution of part of the $\mathrm{Mg}$ by $\mathrm{Zn}$ or Fe${ }^{2+}$ changed the intensity of some XRD lines: for example, the lines corresponding to hkl (011), (002) and (023) increased in opposition to the lines (012) and (041) that decreased (Figure 6). By other means, the substitution of part of the $\mathrm{Al}$ by $\mathrm{Fe}^{3+}$ revealed differences in the intensity of those lines depending on if it occurred on Al1, Al2 or both sites (Figure 7). Nevertheless, the observation of these differences in the experimental patterns was not clear; the intensity of lines (011) and (023) was very low in all XRD patterns, and lines (002), (012) plus (041) were less intense in all samples compared to sample 22-white.

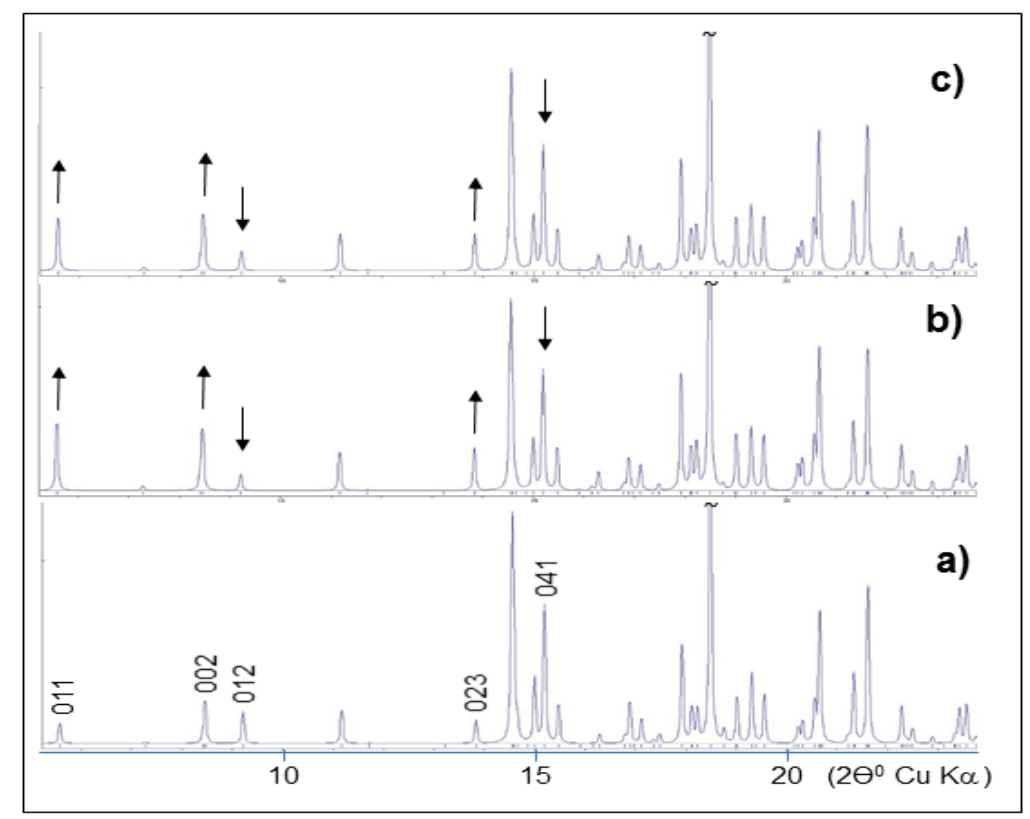

Figure 6. XRD patterns simulation obtained with PowderCell program: (a) original data of pickeringite, $\mathrm{MgAl}_{2}\left(\mathrm{SO}_{4}\right)_{4} \cdot 22 \mathrm{H}_{2} \mathrm{O}$, with $\mathrm{Mg}: \mathrm{Mn}$ occupancy of 0.93:0.07 [33]; (b) $\mathrm{Mg}: \mathrm{Zn}$ occupancy, 0.5:0.5; (c) $\mathrm{Mg}: \mathrm{Fe}, 0.5: 0.5$. The Miller indices are indicated for the lines that change the intensity, compared to the original data, with the variation indicated by arrows. 


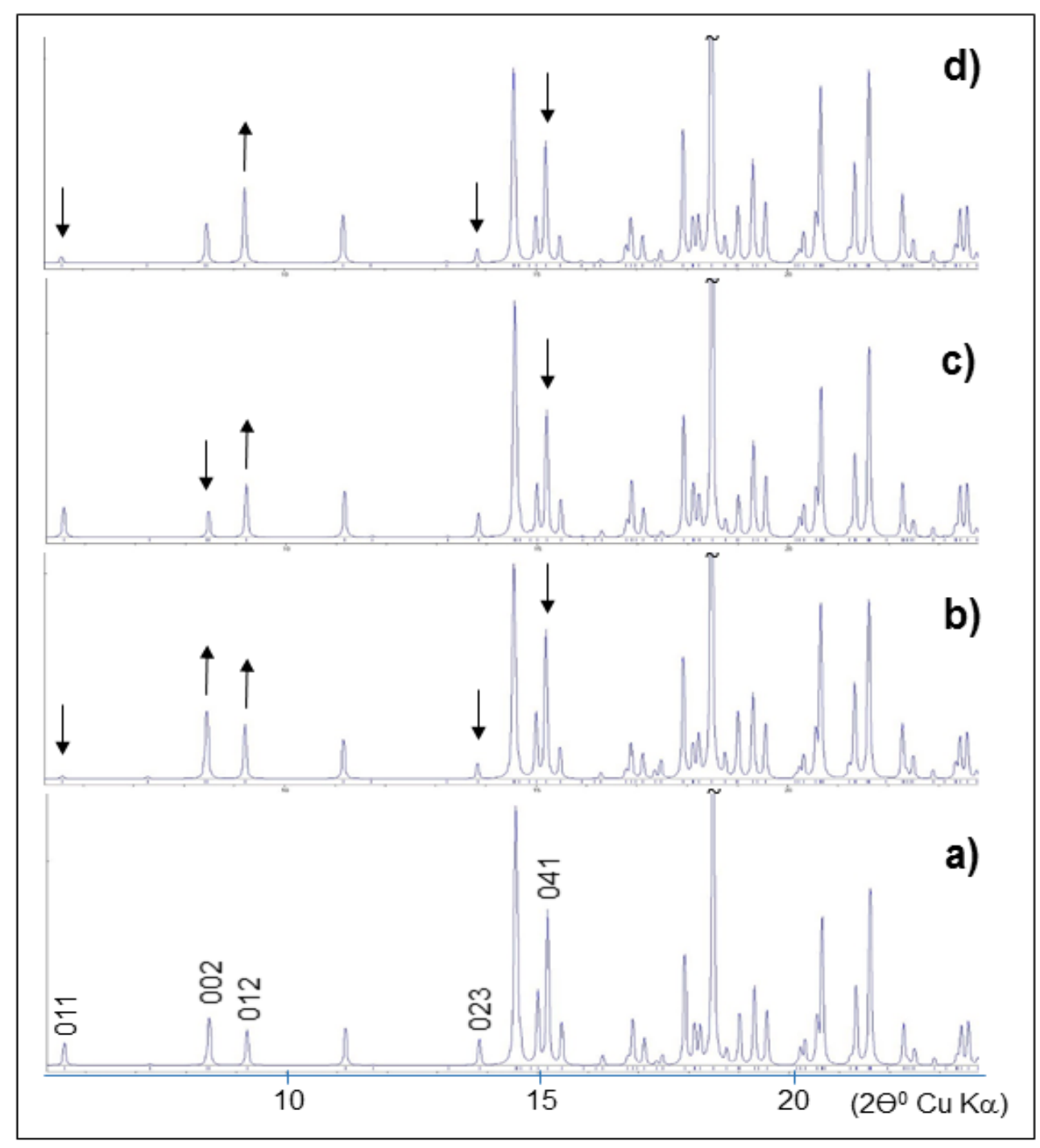

Figure 7. XRD patterns simulation obtained with PowderCell program: (a) original data of pickeringite, $\mathrm{MgAl}_{2}\left(\mathrm{SO}_{4}\right)_{4} \cdot 22 \mathrm{H}_{2} \mathrm{O}$, with $\mathrm{Al} 1$ and $\mathrm{Al} 2$ sites totally occupied by aluminium [33]; (b) $\mathrm{Al}: \mathrm{Fe}$ occupancy in Al1 site, 0.5:0.5; (c) Al:Fe in Al2 site, 0.5:0.5; (d) Al:Fe occupancy in both Al1 and Al2 sites, 0.5:0.5. The Miller indices are indicated for the lines that change the intensity, compared to the original data, with the variation indicated by arrows.

Halotrichite, pickeringite and even apjohnite have similar XRD patterns, the distinction between them shown only through chemical analysis [25]. Thus, chemical analyses were obtained for the two white and two orange samples (Table 2), and the number of atoms on the basis of four sulphur atoms was then calculated. The possibility of the presence of phases in vestigial content not detected by XRD (Figure 5), due to the low content or overlap with other lines, cannot be ruled out. In this way, the approximate chemical formula, $\mathrm{AB}_{2}\left(\mathrm{SO}_{4}\right)_{4} \cdot 22 \mathrm{H}_{2} \mathrm{O}$, can be calculated (Table 3). Samples 20 and 22 are both white, and chemically they are halotrichite and pickeringite, respectively (Table 3, Figure 8). Since samples 19 and 25 were both orange, to maintain the theoretical ratio $A: B=1: 2$, all the iron was assumed to be $\mathrm{Fe}^{3+}$, in substitution of aluminium in the case of fragment 19, and $\frac{1}{4} \mathrm{Fe}^{2+}$ plus $\frac{3}{4} \mathrm{Fe}^{3+}$ in fragment 25. The ternary diagram plotted in Figure 8 shows that they are both pickeringite. 
Table 2. Chemical characterisation obtained through XRF of efflorescence salts.

\begin{tabular}{|c|c|c|c|c|c|c|c|c|c|c|c|c|}
\hline & \multicolumn{3}{|c|}{ 20-White } & \multicolumn{3}{|c|}{ 22-White } & \multicolumn{3}{|c|}{ 19-Orange } & \multicolumn{3}{|c|}{ 25-Orange } \\
\hline & $\%$ & Nr. & Atoms & $\%$ & Nr. & Atoms & $\%$ & Nr. & Atoms & $\%$ & Nr. & Atoms \\
\hline $\mathrm{O}$ & 53.1 & - & - & 53.8 & - & - & 50.2 & - & - & 51.0 & - & - \\
\hline $\mathrm{Na}$ & - & - & - & 1.3 & 0.056 & 0.28 & - & - & - & - & - & - \\
\hline $\mathrm{Mg}$ & 0.2 & 0.008 & 0.04 & 2.8 & 0.115 & 0.57 & 1.8 & 0.074 & 0.40 & 1.3 & 0.053 & 0.27 \\
\hline $\mathrm{Al}$ & 8.6 & 0.319 & 1.56 & 9.2 & 0.341 & 1.70 & 7.2 & 0.267 & 1.44 & 6.5 & 0.241 & 1.24 \\
\hline $\mathrm{Si}$ & 0.9 & 0.032 & 0.16 & 2.2 & 0.078 & 0.39 & 0.6 & 0.021 & 0.11 & 0.4 & 0.014 & 0.07 \\
\hline $\mathrm{P}$ & 0.6 & 0.019 & 0.09 & 0.8 & 0.026 & 0.13 & 0.8 & 0.026 & 0.140 & 0.6 & 0.019 & 0.10 \\
\hline$S$ & 26.2 & 0.817 & 4 & 25.8 & 0.804 & 4 & 23.8 & 0.742 & 4 & 24.9 & 0.776 & 4 \\
\hline $\mathrm{K}$ & 0.2 & 0.005 & 0.02 & 0.2 & 0.005 & 0.02 & 0.2 & 0.005 & 0.03 & 0.06 & 0.002 & 0.01 \\
\hline $\mathrm{Ca}$ & 0.3 & 0.007 & 0.03 & 0.6 & 0.015 & 0.07 & 0.4 & 0.010 & 0.05 & 0.4 & 0.010 & 0.05 \\
\hline $\mathrm{Mn}$ & 0.06 & 0.001 & 0.00 & 0.2 & 0.004 & 0.02 & 2.1 & 0.038 & 0.20 & 0.2 & 0.004 & 0.02 \\
\hline $\mathrm{Fe}$ & 8.8 & 0.158 & 0.77 & 0.4 & 0.007 & 0.03 & 7.3 & 0.131 & 0.71 & 10.6 & 0.190 & 0.98 \\
\hline Co & - & - & - & 0.03 & 0.0003 & 0.00 & 0.04 & 0.0007 & 0.00 & - & - & - \\
\hline $\mathrm{Ni}$ & - & - & - & 0.02 & 0.0003 & 0.00 & 0.03 & 0.0005 & 0.00 & 0.04 & 0.0007 & 0.00 \\
\hline $\mathrm{Cu}$ & 0.8 & 0.012 & 0.06 & 0.6 & 0.009 & 0.04 & 1.5 & 0.024 & 0.13 & 1.0 & 0.016 & 0.08 \\
\hline $\mathrm{Zn}$ & 0.02 & 0.0003 & 0.00 & 1.8 & 0.028 & 0.14 & 3.8 & 0.058 & 0.31 & 2.9 & 0.044 & 0.23 \\
\hline Total & 99.78 & - & - & 99.7 & - & - & 99.77 & - & - & 99.90 & - & - \\
\hline
\end{tabular}

Table 3. Calculated chemical formula (based on XRF data) for the Algares samples from the halotrichite group, $\mathrm{AB}_{2}\left(\mathrm{SO}_{4}\right)_{4} \cdot 22 \mathrm{H}_{2} \mathrm{O}$; $\mathrm{x}$-number of water molecules, not calculated, as loss on ignition was not obtained; principal cations on A site are assigned in bold. $\mathrm{H}$-halotrichite; $\mathrm{P}$-pickeringite.

\begin{tabular}{|c|c|c|c|}
\hline Sample & Chemical Formula & A:B & Mineral \\
\hline 20-white & $\left(\mathrm{Fe}_{0.77} \mathrm{Cu}_{0.06} \mathrm{Mg}_{0.04} \mathrm{Ca}_{0.03}\right) \mathrm{Al}_{1.56}\left(\mathrm{SO}_{4}\right)_{4} \cdot \times \mathrm{H}_{2} \mathrm{O}$ & $0.90: 1.56 \cong 1: 2$ & $\mathrm{H}$ \\
\hline 22-white & $\left(\mathrm{Mg}_{0.57} \mathrm{Zn}_{0.14} \mathrm{Ca}_{0.07} \mathrm{Cu}_{0.04} \mathrm{Fe}_{0.03} \mathrm{Mn}_{0.02}\right) \mathrm{Al}_{1.70}\left(\mathrm{SO}_{4}\right)_{4} \cdot \times \mathrm{H}_{2} \mathrm{O}$ & $0.87: 1.70 \cong 1: 2$ & $\mathrm{P}$ \\
\hline \multirow[t]{2}{*}{ 19-orange } & $\left(\mathrm{Fe}_{0.71} \mathrm{Mg}_{0.40} \mathrm{Zn}_{0.31} \mathrm{Mn}_{0.20} \mathrm{Cu}_{0.13} \mathrm{Ca}_{0.05}\right) \mathrm{Al}_{1.44}\left(\mathrm{SO}_{4}\right)_{4} \cdot \mathrm{xH}_{2} \mathrm{O}$ & $1.8: 1.44 \cong 1: 1$ & \\
\hline & $\left(\mathrm{Mg}_{0.40} \mathrm{Zn}_{0.31} \mathrm{Mn}_{0.20} \mathrm{Cu}_{0.13} \mathrm{Ca}_{0.05}\right)\left(\mathrm{Al}_{1.44} \mathrm{Fe}_{0.71}\right)\left(\mathrm{SO}_{4}\right)_{4} \cdot \mathrm{xH}_{2} \mathrm{O}$ & $1.09: 2.15 \cong 1: 2$ & $\mathrm{P}$ \\
\hline \multirow[t]{2}{*}{ 25-orange } & $\left(\mathrm{Fe}_{0.98} \mathrm{Mg}_{0.27} \mathrm{Zn}_{0.23} \mathrm{Cu}_{0.08} \mathrm{Ca}_{0.05} \mathrm{Mn}_{0.02}\right) \mathrm{Al}_{1.24}\left(\mathrm{SO}_{4}\right)_{4} \cdot \mathrm{xH}_{2} \mathrm{O}$ & $1.63: 1.24 \cong 1: 1$ & \\
\hline & $\left(\mathrm{Mg}_{0.27} \mathrm{Fe}_{0.24} \mathrm{Zn}_{0.23} \mathrm{Cu}_{0.08} \mathrm{Ca}_{0.05} \mathrm{Mn}_{0.02}\right)\left(\mathrm{Al}_{1.24} \mathrm{Fe}_{0.72}\right)\left(\mathrm{SO}_{4}\right)_{4} \cdot \mathrm{xH}_{2} \mathrm{O}$ & $0.89: 1.96 \cong 1: 2$ & $\mathrm{P}$ \\
\hline
\end{tabular}

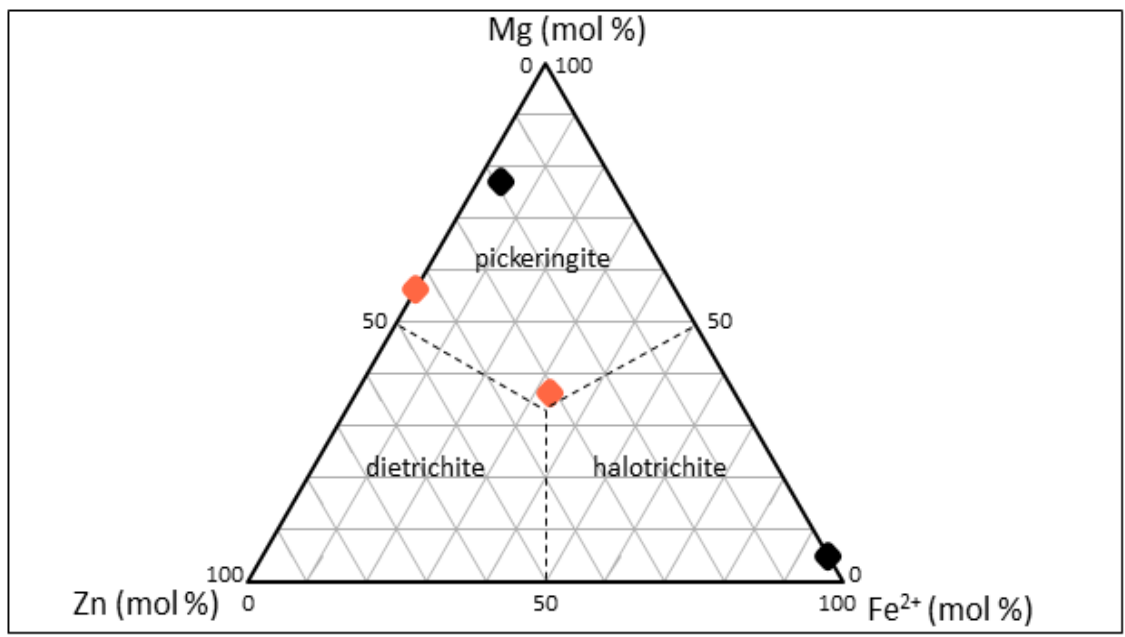

Figure 8. Ternary diagram [36] $\mathrm{Fe}^{2+} / \mathrm{Mg} / \mathrm{Zn}$ (in terms of mole percent) for the Algares samples from the halotrichite group (based on XRF data); orange diamonds-orange samples; black diamondswhite samples.

Collected SEM images illustrate the aggregates of fine-acicular crystals (Figure 9), showing the typical morphology of these minerals in accordance with published papers (e.g., [22,26,36-38]). The approximate chemical formula was also calculated through EDSquantification (Tables 4 and 5), following the same methodology used before, based on four 
sulphur atoms, maintaining the ratio $\mathrm{A}: \mathrm{B} \cong 1: 2$. The respective ternary diagram (Figure 10) corroborates the results achieved previously.
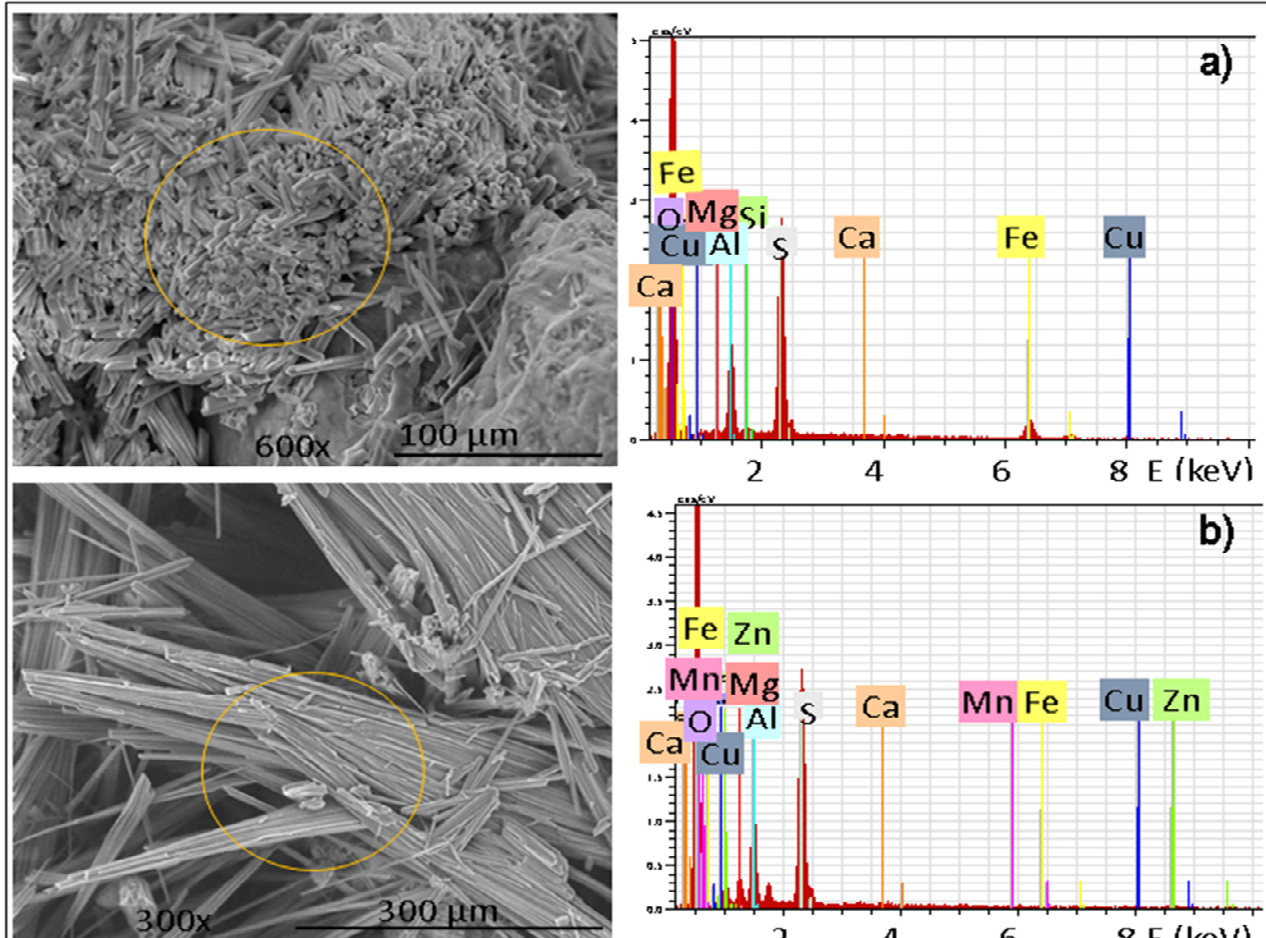

b)
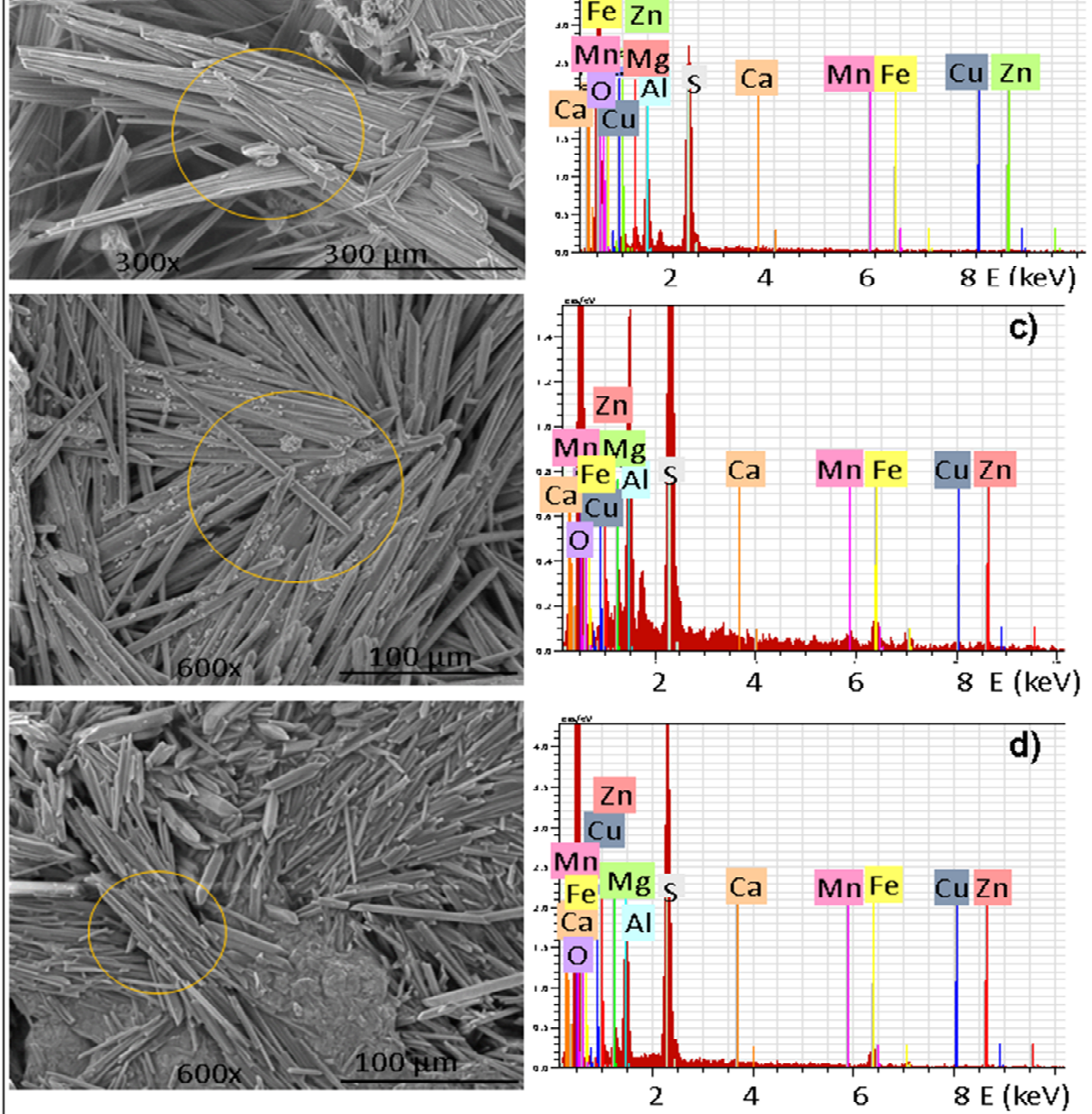

Figure 9. SEM images showing acicular crystals morphology and chemical composition (EDS): (a) halotrichite (sample 20-white); (b) pickeringite (sample 22-white); (c) orange pickeringite (sample 19-orange); (d) orange pickeringite (sample 25-orange). The yellow circle shows the area used for quantification. 
Table 4. Chemical characterisation of the Algares samples obtained through SEM-EDS analyses.

\begin{tabular}{|c|c|c|c|c|c|c|c|c|c|c|c|c|}
\hline & \multicolumn{3}{|c|}{ 20-White } & \multicolumn{3}{|c|}{ 22-White } & \multicolumn{3}{|c|}{ 19-Orange } & \multicolumn{3}{|c|}{ 25-Orange } \\
\hline & $\%$ & Nr. & Atoms & $\%$ & Nr. & Atoms & $\%$ & Nr. & Atoms & $\%$ & Nr. & Atoms \\
\hline $\mathrm{O}$ & 85.70 & - & - & 83.47 & - & - & 84.44 & - & - & 85.15 & - & - \\
\hline $\mathrm{Mg}$ & 0.17 & 0.007 & 0.12 & 1.37 & 0.056 & 0.74 & 1.16 & 0.048 & 0.78 & 1.37 & 0.056 & 0.99 \\
\hline $\mathrm{Al}$ & 3.58 & 0.133 & 2.26 & 4.48 & 0.166 & 2.18 & 3.94 & 0.146 & 2.38 & 4.07 & 0.151 & 2.66 \\
\hline $\mathrm{Si}$ & 0.30 & 0.011 & 0.19 & - & - & - & - & - & - & - & - & - \\
\hline S & 7.53 & 0.235 & 4 & 9.76 & 0.304 & 4 & 7.85 & 0.245 & 4 & 7.27 & 0.227 & 4 \\
\hline $\mathrm{Ca}$ & 0.02 & 0.0005 & 0.01 & 0.01 & 0.0002 & 0.00 & 0.02 & 0.0005 & 0.00 & 0.01 & 0.0002 & 0.00 \\
\hline $\mathrm{Mn}$ & - & - & - & 0.06 & 0.001 & 0.01 & 0.36 & 0.007 & 0.11 & 0.03 & 0.0005 & 0.01 \\
\hline $\mathrm{Fe}$ & 2.42 & 0.043 & 0.73 & 0.03 & 0.005 & 0.01 & 1.40 & 0.025 & 0.41 & 1.56 & 0.028 & 0.49 \\
\hline $\mathrm{Cu}$ & 0.28 & 0.004 & 0.07 & 0.18 & 0.003 & 0.04 & 0.19 & 0.003 & 0.05 & 0.07 & 0.001 & 0.02 \\
\hline $\mathrm{Zn}$ & - & - & - & 0.62 & 0.009 & 0.12 & 0.64 & 0.010 & 0.16 & 0.47 & 0.007 & 0.12 \\
\hline Total & 100.00 & - & - & 99.98 & - & - & 100.00 & - & - & 100.00 & - & - \\
\hline
\end{tabular}

Table 5. Calculated chemical formula (based on SEM-EDS data) for the Algares samples from the halotrichite group, $\mathrm{AB}_{2}\left(\mathrm{SO}_{4}\right)_{4} \cdot 22 \mathrm{H}_{2} \mathrm{O}$; $\mathrm{x}$-number of water molecules; principal cations on A site are assigned in bold. $\mathrm{H}$-halotrichite; $\mathrm{P}$ - pickeringite.

\begin{tabular}{|c|c|c|c|}
\hline Sample & Chemical Formula & A:B & Mineral \\
\hline 20-white & $\left(\mathrm{Fe}_{0.73} \mathrm{Mg}_{0.12} \mathrm{Cu}_{0.07} \mathrm{Ca}_{0.01}\right) \mathrm{Al}_{2.26}\left(\mathrm{SO}_{4}\right)_{4} \cdot \times \mathrm{H}_{2} \mathrm{O}$ & $0.93: 2.26 \cong 1: 2$ & $\mathrm{H}$ \\
\hline 22-white & $\left(\mathrm{Mg}_{0.74} \mathrm{Zn}_{0.12} \mathrm{Ca}_{0.04} \mathrm{Cu}_{0.04} \mathrm{Fe}_{0.01} \mathrm{Mn}_{0.01}\right) \mathrm{Al}_{2.18}\left(\mathrm{SO}_{4}\right)_{4} \cdot \mathrm{xH}_{2} \mathrm{O}$ & $0.92: 2.18 \cong 1: 2$ & $\mathrm{P}$ \\
\hline 19-orange & $\left(\mathrm{Mg}_{0.78} \mathrm{Fe}_{0.41} \mathrm{Zn}_{0.16} \mathrm{Mn}_{0.11} \mathrm{Cu}_{0.05}\right) \mathrm{Al}_{2.38}\left(\mathrm{SO}_{4}\right)_{4} \cdot \times \mathrm{H}_{2} \mathrm{O}$ & $1.51: 2.38$ & \\
\hline \multirow{3}{*}{ 25-orange } & $\left(\mathbf{M g}_{0.78} \mathrm{Fe}_{0.20} \mathbf{Z n}_{0.16} \mathrm{Mn}_{0.11} \mathrm{Cu}_{0.05}\right)\left(\mathrm{Al}_{2.38} \mathrm{Fe}_{0.21}\right)\left(\mathrm{SO}_{4}\right)_{4} \cdot \mathrm{xH}_{2} \mathrm{O}$ & $1.30: 2.59 \cong 1: 2$ & $\mathrm{P}$ \\
\hline & $\left(\mathrm{Mg}_{0.99} \mathrm{Fe}_{0.49} \mathrm{Zn}_{0.12} \mathrm{Cu}_{0.02} \mathrm{Mn}_{0.01}\right) \mathrm{Al}_{2.66}\left(\mathrm{SO}_{4}\right)_{4} \cdot \times \mathrm{H}_{2} \mathrm{O}$ & $1.63: 2.66$ & \\
\hline & $\left(\mathrm{Mg}_{0.99} \mathrm{Fe}_{\mathbf{0 . 2 4}} \mathrm{Zn}_{0.12} \mathrm{Cu}_{0.02} \mathrm{Mn}_{0.01}\right)\left(\mathrm{Al}_{2.66} \mathrm{Fe}_{0.25}\right)\left(\mathrm{SO}_{4}\right)_{4} \cdot \times \mathrm{H}_{2} \mathrm{O}$ & $1.38: 2.91 \cong 1: 2$ & $\mathrm{P}$ \\
\hline
\end{tabular}

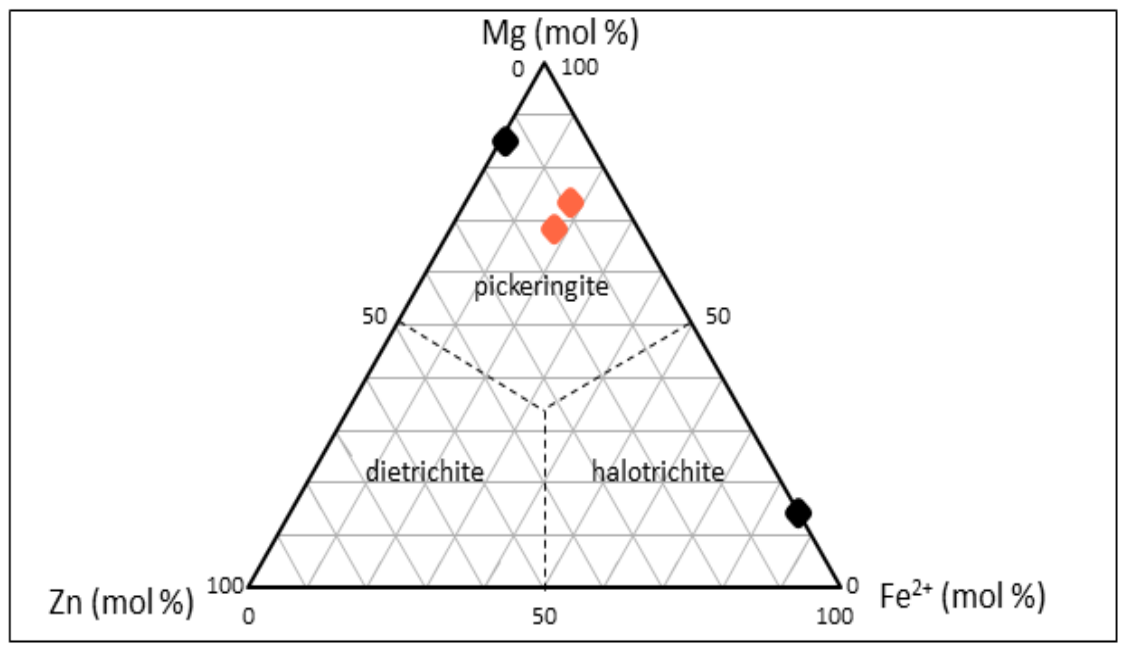

Figure 10. Ternary diagram [36] $\mathrm{Fe}^{2+} / \mathrm{Mg} / \mathrm{Zn}$ (in terms of mole percent) for the Algares samples from the halotrichite group (based on SEM-EDS data); orange diamonds-orange samples; black diamonds—white samples.

DTA-TG assays were also performed (Figure 11). The intense endothermic peaks at approximately $150{ }^{\circ} \mathrm{C}$ and those at $310-340^{\circ} \mathrm{C}$ correspond to dehydration [27]. The peak at $405-420^{\circ} \mathrm{C}$ is attributed to the liberation of the most strongly bound water molecules or to the decomposition of intermediate products containing hydroxyl groups. The large endothermic peak at about $800{ }^{\circ} \mathrm{C}$ corresponds to the dissociation of aluminium and iron sulphates. The increase of total iron in the pickeringite structure caused a decrease in the temperature of this peak [25]; indeed, for pickeringite samples, the observed temperature was $808{ }^{\circ} \mathrm{C}$ for fragment 22 -white, plus 778 and $772{ }^{\circ} \mathrm{C}$ for 19 -orange and 25-orange, respectively; the iron content was $0.03 \%, 1.40 \%$ and $1.56 \%$, respectively (Table 4 ). The 
temperature observed for sample 20-white (halotrichite) was $762{ }^{\circ} \mathrm{C}$, with an iron content of $2.42 \%$.

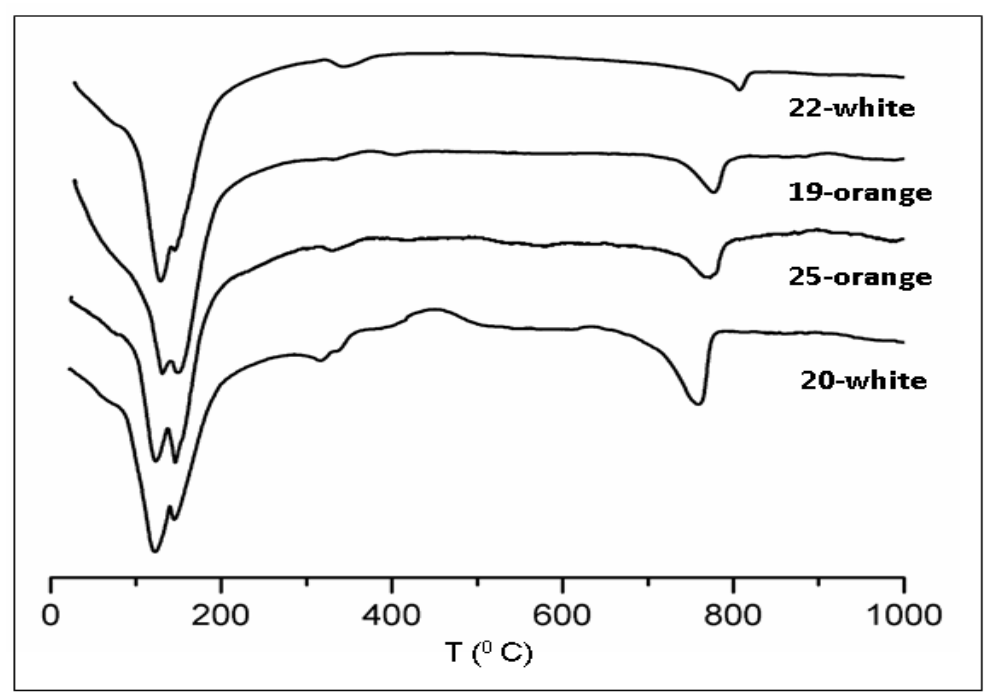

Figure 11. DTA curves for halotrichite (20-white) and pickeringite (19-orange, 22-white, 25-orange) samples.

\section{Conclusions}

Several methods and analytical techniques (XRD, XRF-WDS, SEM-EDS, DTA-TG) were used in this study to characterise crystal aggregate samples belonging to the halotrichite group, collected from the walls of the Algares 30-level adit in the Aljustrel mine (Algares deposit, IPB massive sulphides) during a rehabilitation intervention for its valorisation as a mining and geological heritage site. Indeed, the existence of solid solution between members of this group makes their identification only through XRD difficult. Of the 25 fragments selected from the 19 samples, the majority were identified as whitish pickeringite, along with two iron-rich pickeringite (the orange ones) and one white halotrichite. In fact, pickeringite was the only magnesium mineral found coating the adit walls [16], resulting from the oxidation of sulphides and from the percolation of aqueous solution of $\mathrm{Mg}^{2+} / \mathrm{Fe}^{2+} / \mathrm{Fe}^{3+}$ combined with $\mathrm{Al}^{3+}$ from silicates weathering. Hydrothermal Mg-rich chlorite (present in the host felsic volcanic rocks) can also be considered as a source of the magnesium.

Quantitative analyses obtained through SEM-EDS were used to determine the approximate chemical formula of the halotrichite s.s. fragment, corresponding to the formula $\left(\mathrm{Fe}_{0.73} \mathrm{Mg}_{0.12} \mathrm{Cu}_{0.07} \mathrm{Ca}_{0.01}\right) \mathrm{Al}_{2.26}\left(\mathrm{SO}_{4}\right)_{4} \cdot 22 \mathrm{H}_{2} \mathrm{O}$, whereas the formula for pickeringite was found to be $\left(\mathrm{Mg}_{0.74} \mathrm{Zn}_{0.12} \mathrm{Ca}_{0.04} \mathrm{Cu}_{0.04} \mathrm{Fe}_{0.01} \mathrm{Mn}_{0.01}\right) \mathrm{Al}_{2.18}\left(\mathrm{SO}_{4}\right)_{4} \cdot 22 \mathrm{H}_{2} \mathrm{O}$.

The chemical formulas of the iron-rich pickeringite were calculated to maintain the ratio $\mathrm{A}: \mathrm{B} \cong 1: 2$ in accordance with the general formula of the halotrichite group, $\mathrm{AB}_{2}\left(\mathrm{SO}_{4}\right)_{4} \cdot 22 \mathrm{H}_{2} \mathrm{O}: \quad\left(\mathrm{Mg}_{0.78} \mathrm{Fe}_{0.20} \mathrm{Zn}_{0.16} \mathrm{Mn}_{0.11} \mathrm{Cu}_{0.05}\right)\left(\mathrm{Al}_{2.38} \mathrm{Fe}_{0.21}\right)\left(\mathrm{SO}_{4}\right)_{4} \cdot 22 \mathrm{H}_{2} \mathrm{O}$ and $\left(\mathrm{Mg}_{0.99} \mathrm{Fe}_{0.24} \mathrm{Zn}_{0.12} \mathrm{Cu}_{0.02} \mathrm{Mn}_{0.01}\right)\left(\mathrm{Al}_{2.66} \mathrm{Fe}_{0.25}\right)\left(\mathrm{SO}_{4}\right)_{4} \cdot 22 \mathrm{H}_{2} \mathrm{O}$.

If it is not the high iron content that is responsible for the orange colour, as is the case of the white halotrichite, surely the trivalent state of iron in partial substitution of aluminium is responsible for the samples' colour, even when the mixed divalent-trivalent state is present (iron-rich pickeringite). Future spectroscopic studies concerning the presence of $\mathrm{Fe}^{2+}$ and/or $\mathrm{Fe}^{3+}$ are foreseen using synchrotron radiation. The adsorbed water of the samples, due to the constant humidity of the adit walls, intensifies their colour, giving them the peculiar orange/brownish hue.

Author Contributions: Conceptualization, T.P.S., J.X.M., D.d.O. and J.P.V.; methodology, T.P.S. and J.P.V.; investigation, T.P.S., J.X.M., D.d.O., I.M., P.G., L.A., F.C., U.D.M. and J.P.V.; writing—original draft preparation, T.P.S., J.X.M. and D.d.O.; writing—review and editing, T.P.S., J.X.M., D.d.O., I.M., 
P.G., L.A., F.C., U.D.M. and J.P.V.; visualization, T.P.S.; funding acquisition, J.X.M., J.P.V., F.C., U.D.M. All authors have read and agreed to the published version of the manuscript.

Funding: Funding from FEDER (Fundo Europeu de Desenvolvimento Regional)/INTERREG POCTEP GEO-FPI - (Ref. 0052-GEO-FPI-5-E) and EXPLORA, Op ALT20-03-0145-FEDER-000025. Funding by Alentejo 2020, Portugal 2020 and the European Union (ERDF) is acknowledged. J.P. Veiga acknowledges FEDER funds through the COMPETE 2020 Programme and National Funds through the FCT-Portuguese Foundation for Science and Technology under the project UID/CTM/50025/2019, and SFRH/BD/145308/2019 (F.Carvalho) plus UIDP/50025/2020 (U.D. Menda), and funding from the European Institute of Innovation and Technology (EIT), a body of the European Union, under Horizon 2020, the EU Framework Programme for Research and Innovation, through the MineHeritage Project (PA 18111).

Acknowledgments: Thanks are due to Ana Rita Silva and Marta Silva for focus stacking the stereomicroscope images. The EDM Company and the Municipality of Aljustrel are both thanked for allowing access to the +30 Algares adit.

Conflicts of Interest: The authors declare no conflict of interest.

\section{References}

1. Barriga, F.J.A.S.; Carvalho, D.; Ribeiro, A. Introduction to the Iberian Pyrite Belt. In Geology and VMS Deposits of the Iberian Pyrite Belt; Barriga, F.J.A.S., Carvalho, D., Eds.; SEG Neves Corvo Field Conference Guidebook; Society of Economic Geologists: Littleton, CO, USA, 1997; Volume 27, pp. 1-20.

2. Almodóvar, G.R.; Yesares, L.; Sáez, R.; Toscano, M.; González, F.; Pons, J.M. Massive sulfide ores in the Iberian Pyrite Belt: Mineralogical and textural evolution. Minerals 2019, 9, 653. [CrossRef]

3. Matos, J.X.; Martins, L.P.; Oliveira, J.T.; Pereira, Z.; Batista, M.J.; Quental, L. Pyrite Route in the Portuguese sector of the Iberian Pyrite Belt, challenges for a sustained development of geological tourism and mining. In Rutas Minerales en Iberoamérica; Carrion, P., Ed.; Cámara Ecuatoriana del Libro-Núcleo de Pichincha: Guayaquil, Equador, 2008; pp. 136-155. (In Portuguese)

4. Leitão, J. Geology of the Aljustrel Massive Sulfides Deposits. In Geology and VMS Deposits of the Iberian Pyrite Belt; SEG Guidebook Series V; Society of Economic Geologists: Littleton, CO, USA, 1997; Volume 27, pp. 82-97.

5. Leitão, J. Geology of the massive sulphide deposits of Aljustrel. In Livro Guia das Excursões do V Congresso Nacional de Geologia; IGM, Ed.; Portugal, 1998; pp. 91-100. (In Portuguese)

6. $\quad$ Luís, A.T.; Durães, N.; Silva, E.F.; Ribeiro, S.; Silva, A.J.F.; Patinha, C.; Almeida, S.F.P.; Azevedo, M.R. Tracking multiple Sr sources through variations in ${ }^{87} \mathrm{Sr} /{ }^{86} \mathrm{Sr}$ ratios of surface waters from the Aljustrel massive sulphide mining area: Geological versus anthropogenic inputs. Appl. Geochem. 2019, 102, 108-120. [CrossRef]

7. Matos, J.X. Expansion and development of the Pyrite Route through the inclusion of the geological gardens of Algares and Lousal, Iberian Pyirite Belt, Portugal. In Rutas Minerales en Iberoamérica; Carrion, P., Ed.; Cámara Ecuatoriana del Libro-Núcleo de Pichincha: Guayaquil, Equador, 2009; pp. 113-121. (In Portuguese)

8. Gaspar, O.C. Microscopy and petrology of ores applied to the genesis, exploration and mineralogy of the massive sulphides of the Aljustrel and Neves-Corvo deposits. In Estudos, Notas e Trabalhos, Instituto Geológico e Mineiro; Instituto Geológico e Mineiro: Amadora, Portugal, 1996; Volume 38, pp. 3-195. (In Portuguese)

9. Matos, J.X.; Barriga, F.; Oliveira, V. Alunite veins versus supergene kaolinite-halloysite alteration in the Lagoa Salgada, Algares and S. João, Aljustrel, and S. Domingos massive sulphide deposits, Iberian Pyrite Belt, Portugal. In Proceedings of the VI Congresso Nacional de Geologia, Caparica, Portugal, 4-6 June 2003.

10. Matos, J.X.; Barriga, F.J.A.S.; Relvas, J.M.R.S. Acid sulphate alteration in the Iberian Pyrite Belt. In Proceedings of the 14th SGA Biennial Meeting, Mineral Resources to Discover, Québec City, QC, Canada, 20-23 August 2017; Volume II. pp. 625-628.

11. Matos, J.X.; Barriga, F.J.A.S.; Relvas, J.M.R.S. Acid sulphate alteration at the Lagoa Salgada, Aljustrel and São Domingos VMS deposits, Iberian Pyrite Belt, Portugal: Mineral exploration guidelines. In Abs. EGU General Assembly Session ITS2.2/ERE4.4, The New Roadmap for Mineral Exploration; EGU: Vienna, Austria, 2019.

12. Matos, J.X.; Martins, A.; Rego, M.; Mateus, A.; Pinto, A.; Figueiras, J.; Silva, E. Roman slag distribution in the Portuguese sector of the Iberia Pyrite Belt. In Actas of the "V Congreso Internacional sobre Minería y Metalurgia Históricas en el Suroeste Europeo (León 2008)"; Mata-Perelló, J.M., Iabat, L.T., Prieto, M.N.F., Eds.; SEDPGYM: Madrid, Spain, 2011; pp. 567-576.

13. Andrade, R.F. The mine of Aljustrel. Bol. Minas 1967, 4, 73-90. (In Portuguese)

14. Andrade, R.; Schermerhorn, L. Aljustrel and Gavião. In Livro Guia da Excursão 4. I Congresso Hispano-Luso-Americano de Geologia Económica; Carvalho, D., Goinhas, J., Schermerhorn, L.J.S., Eds.; Direcção-Geral de Minas e Serviços Geológicos: Lisboa, Portugal, 1971; pp. 32-59.

15. Matos, J.X.; Martins, L.P. Environmental rehabilitation of mining areas in the Portuguese sector of the Iberian Pyrite Belt: State of the art and future perspectives. Bol. Geol. Min. 2006, 117, 289-304. (In Portuguese)

16. Silva, T.P.; Matos, J.X.; De Oliveira, D.; Veiga, J.P.; Morais, I.; Gonçalves, P.; Albardeiro, L. Mineral Inventory of the Algares 30-Level Adit, Aljustrel Mine, Iberian Pyrite Belt, Portugal. Minerals 2020, 10, 853. [CrossRef] 
17. Buckby, T.; Black, S.; Coleman, M.L.; Hodson, M.E. Fe-sulphate-rich evaporative mineral precipitates from the Rio Tinto, southwest Spain. Min. Mag. 2003, 67, 263-278. [CrossRef]

18. Sánchez-España, J. Acid mine drainage in the Iberian Pyrite Belt: An overview with special emphasis on generation mechanisms, aqueous composition and associated mineral phases. Macla 2008, 10, 34-43.

19. Parafiniuk, J.; Siuda, R.; Borkowski, A. Sulphate and arsenate minerals as environmental indicators in the weathering zones of selected ore deposits, Western Sudetes, Poland. Acta Geol. Pol. 2016, 66, 493-508. [CrossRef]

20. Košek, F.; Culka, A.; Fornasini, L.; Vandenabeele, P.; Rousaki, A.; Mirão, J.; Bersani, D.; Candeias, A.; Jehlička, J. Application of a handheld Raman spectrometer for the screening of colored secondary sulfates in abandoned mining areas-The case of the São Domingos Mine (Iberian Pyrite Belt). J Raman Spectrosc. 2020, 51, 1186-1199. [CrossRef]

21. Valente, T.; Gomes, P.; Braga, M.A.S.; Pamplona, J.; Antunes, I.M.; Reyes, C.A.R.; Moreno, F. Mineralogical Attenuation Processes Associated with The Evolution of Acid Mine Drainage in Sulfide-Rich Mine Wastes. In Proceedings of the IMWA 2019 "Mine Water: Technological and Ecological Challenges", Perm, Russia, 15-19 July 2019; Wolkersdorfer, C., Khayrulina, E., Polyakova, S., Bogush, A., Eds.; IMWA: Perm, Russia, 2019; pp. 146-152.

22. Ribeiro, J.; Taffarel, S.R.; Sampaio, C.H.; Flores, D.; Silva, L.F.O. Mineral speciation and fate of some hazardous contaminants in coal waste pile from anthracite mining in Portugal. Int. J. Coal Geol. 2013, 109-110, 15-23. [CrossRef]

23. Palache, C.; Berman, H.; Frondel, C. Dana's System of Mineralogy, 7th ed.; John Wiley \& Sons, Inc.: Hoboken, NJ, USA, 1951; Volume II, pp. 522-529.

24. Kostov, I. Mineralogy; Oliver and Boyd Ltd.: Edinburgh, UK, 1968; p. 493.

25. Parafiniuk, J. Sulfate minerals and their origin in the weathering zone of the pyrite-bearing schists at Wiesciszowice (Rudawy Janowickie Mts, Western Sudetes). Acta Geol. Pol. 1996, 46, 353-414.

26. Hammarstrom, J.M.; Seal, R.R., II; Meier, A.L.; Kornfeld, J.M. Secondary sulfate minerals associated with acid drainage in the eastern US: Recycling of metals and acidity in surficial environments. Chem. Geol. 2005, 215, 407-431. [CrossRef]

27. Parafiniuk, J. Fibroferrite, slavikite and pickeringite from the oxidation zone of pyrite-bearing schists in Wiesciszowice (Lower Silesia). Miner. Pol. 1991, 22, 3-15.

28. Jambor, J.L.; Nordstrom, D.K.; Alpers, C.N. Metal-sulfate Salts from Sulfide Mineral Oxidation. In Reviews in Mineralogy and Geochemistry, Sulfate Minerals-Crystallography, Geochemistry, and Environmental Significance; Alpers, C.N., Jambor, J.L., Nordstrom, D.K., Eds.; Mineralogical Society of America: Chantilly, VA, USA, 2000; Volume 40, pp. 303-350.

29. Menchetti, S.; Sabelli, C. The halotrichite group: The crystal structure of apjohnite. Min. Mag. 1976, 40, 599-608. [CrossRef]

30. Ballirano, P. Crystal chemistry of the halotrichite group $\mathrm{XAl}_{2}\left(\mathrm{SO}_{4}\right)_{4} \cdot 22 \mathrm{H}_{2} \mathrm{O}$ : The $X=\mathrm{Fe}-\mathrm{Mg}-\mathrm{Mn}-\mathrm{Zn}$ compositional tetrahedron. Eur. J. Mineral. 2006, 18, 463-469. [CrossRef]

31. Cotterell, T.F. A review of halotrichite group minerals in Wales. UK J. Mines Miner. 2009, 30, $43-47$.

32. Joeckel, R.M.; Wally, K.D.; Fischbein, S.A.; Hanson, P.R. Sulfate Mineral Paragenesis in Pennsylvanian Rocks and the Occurrence of Slavikite in Nebraska. Great Plains Res. 2007, 17, 17-33.

33. Quartieri, S.; Triscari, M.; Viani, A. Crystal structure of the hydrated sulphate pickeringite $\left(\mathrm{MgAl}_{2}\left(\mathrm{SO}_{4}\right)_{4} \cdot 22 \mathrm{H}_{2} \mathrm{O}\right)$ : $\mathrm{X}$-ray powder diffraction study. Eur. J. Mineral. 2000, 12, 1131-1138. [CrossRef]

34. Hawthorne, F.C.; Krivovichev, S.V.; Burns, P.C. The Crystal Chemistry of Sulfate Minerals. In Reviews in Mineralogy and Geochemistry, Sulfate Minerals-Crystallography, Geochemistry, and Environmental Significance; Alpers, C.N., Jambor, J.L., Nordstrom, D.K., Eds.; Mineralogical Society of America: Chantilly, VA, USA, 2000; Volume 40, pp. 1-112.

35. Kraus, W.; Nolze, G. PowderCell for Windows, Version 2.4; Federal Institute for Materials Research and Testing (BAM): Berlin, Germany, 2000.

36. Marszałek, M.; Gawel, A.; Włodek, A. Pickeringite from the Stone Town Nature Reserve in Ciezkowice (the Outer Carpathians, Poland). Minerals 2020, 10, 187. [CrossRef]

37. Valente, T.; Grande, J.A.; de la Torre, M.L. Magnesium and aluminum sulfates in salt efflorescences from acid mine drainage in the Iberian Pyrite Belt (SW Spain). In Proceedings of the IMWA 2016 “Mining Meets Water-Conflicts and Solutions", Leipzig, Germany, 11-15 July 2016; Drebenstedt, C., Paul, M., Eds; Technische Universität Bergakademie: Freiberg, Germany, 2016; pp. $445-450$.

38. Gomes, P.; Valente, T.; Grande, J.A.; Cordeiro, M. Occurrence of sulphate efflorescences in São Domingos mine. Comun. Geol. 2017, 104, 83-89. 